\title{
Evaluation of Anti Microbial Activity and Phytochemical analysis of Organic Solvent extracts of Calotropis gigantea
}

\author{
S.Senthil Kumar ${ }^{1}$, Dr. P.Sivamani ${ }^{2}$,C.Baskaran ${ }^{3}$, Dr. M.Jamal Mohamed*1. \\ ${ }^{1}$ Department of Zoology, C. Abdul Hakeem College, Melvisharam-632 509, Tamilnadu, India. \\ ${ }^{2}$ Microlabs, Institute of Research and Technology, Arcot-632503, Tamilnadu, India \\ ${ }^{3}$ Department of Zoology, Presidency College, Chennai-600 005, Tamilnadu, India.
}

\begin{abstract}
The leaves extract of Calotropis gigantea were screened for its anti microbial and phytochemical activities. The solvents used for the leaves extraction were Ethanol, Methanol, Chloroform and n-Hexane. The extract was tested against infectious diseases causing fungal pathogens such as Aspergillus flavus, Aspergillus niger, Aspergillus fumigates, Candida tropicalis, Candida albicans, and bacterial pathogens such as Bacillus cereus, Salmonella typhi, Proteus mirablis, Escherichia coli and, Pseudomonas aeruginosa using the Agar well diffusion method. The Ethanol extract of Calotropis gigantea showed more activity against fungus like Candida albicans zone of diameter 15.06 \pm 0.11 , Candida tropicalis zone of diameter 13.30 \pm 0.26 and bacteria like Proteus mirablis zone of diameter 12.16 \pm 0.15 and Pseudomonas aeruginosa zone of diameter 8.0 \pm 0.00 when compared to other solvent extracts. In the present study, both in bacteria and fungi Ethanol extract showed a varying degree of inhibition of the growth of tested organism than Methanol, Chloroform, and n-Hexane. The results confirmed that presence of Antifungal and Antibacterial activity in the shade dried extract of Calotropis gigantea against the human pathogenic organisms.
\end{abstract}

Keywords: Calotropis gigantea crude extract, phytochemicals, Antimicrobial activity.

\section{INTRODUCTION}

Calotropis gigantea $\mathrm{R} . \mathrm{Br}$ (Asclepiadaceae) is a xerophytic, erect shrub, growing widely throughout the tropical and subtropical regions of Asia and Africa. This plant is popularly known because it produces large quantity of latex [1]. The plant has potential pharmacological properties. Fractionation of the latex into its rubber and rubber-free fractions affords better insight into its potentials and limitations. A large quantity of latex can be easily collected from its green parts. The abundance of latex (containing alkaloids) in the green parts of the plant reinforces the idea that it produced and accumulated latex as a defense strategy against organisms such as bacteria, fungi and insects [2]. Different plant parts have shown biological activities viz., antipyretic, anti-inflammatory, wound healing, analgesic, antidiarrhoeal, antioxidant and as an antidiabetic, antinociceptive, fibrinogenolytic, anti-coagulant. Latex has good ovicidal and larvicidal properties etc. The prevalence of invasive, opportunistic microbial and fungal infections has increased at an alarming rate especially in immunecompromised individuals. Although it appears to be a great array of antimicrobial and antifungal drugs, there is at present a quest for new generations of antimicrobial and antifungal compounds due to the low efficacy, side effects or resistance associated to the existing drugs [3]. This plant has potential antimicrobial properties against microbial infections [4, 5, 6]. Commercially available antimicrobial agents (antibiotics) are now used to treat diseases arising from microbial infections. A major problem encountered with antibiotics in clinical use is drug resistance, which mostly leads to treatment failure. Other problems with antibiotics include toxicity, high cost, low cost efficacy, etc. This necessitates a continuous search for new antimicrobial agents. Medicinal plants have no doubt remained the major sources of traditional medicine worldwide. This study attempts to determine the phytochemical analysis and antimicrobial effect of Calotropis gigantea. In this report, we provide new information on the antimicrobial activities of $C$. gigantea using known microbial pathogens as tested organisms.

\section{MATERIALS AND METHODS COLLECTION OF PLANT MATERIAL:}

Calotropis gigantea leaf were collected from in Arcot region, Tamilnadu, India and used for this study. At the lab works are done in Microlabs, Institute of Research and technology, Arcot, Tamilnadu.

\section{EXTRACTION OF PLANT MATERIAL:}

They were washed thoroughly with sterile distilled water in order to remove any dirt or filthy particles present on the surface and were shade dried then made into fine powder, this powdered samples $(100 \mathrm{~g} / 100 \mathrm{ml})$ in ethanol, methanol, chloroform and hexane for overnight at room temperature., soxhlet apparatus are used for this extraction. The extract from these solvents are soaked and evaporated under pressure. The leaf extracts were concentrated at $50^{\circ} \mathrm{C}$ and the residue obtained was stored at $4^{\circ} \mathrm{C}$. 
IOSR Journal of Pharmacy

Vol. 2, Issue 3, May-June, 2012, pp.389-394

\section{PHYTOCHEMICAL ANALYSIS OF THE EXTRACT:}

Specific qualitative tests were performed to identify bioactive compounds of pharmacological importance through standard methods. In brief, the phytochemicals such as tannins, alkaloids, saponins, flavonoids, terpenoids, and phenols/polyphenols were qualitatively determined as following:

\section{TEST FOR ALKALOIDS (MAYER'S TEST):}

$2.0 \mathrm{ml}$ of extract was measured in a test tube to which picric acid solution was added. The formation of orange coloration indicated the presence of alkaloids.

\section{TEST FOR CARDIAC GLYCOSIDES (KELLER-KILLANI TEST):}

$5 \mathrm{ml}$ of plant extracts was treated with $2 \mathrm{ml}$ of glacial acetic acid containing one drop of ferric chloride solution. A brown ring of the interface indicates a deoxysugar characteristic of cardenolides. A violet ring may appear below the brown ring, while in the acetic acid layer, a greenish ring may form just gradually throughout thin layer which shows the presence of Cardiac glycosides.

\section{TEST FOR TANNINS:}

The substance (extracts) mixed with basic lead acetate solution. Formation of white precipitate indicates the presence of Tannins.

\section{TEST FOR SAPONINS:}

Froth test for saponins was used. $1 \mathrm{~g}$ of the sample was weighed into a conical flask in which $10 \mathrm{ml}$ of sterile distilled water was added and boiled for $5 \mathrm{~min}$. The mixture was filtered and $2.5 \mathrm{ml}$ of the filtrate was added to $10 \mathrm{ml}$ of sterile distilled water in a test tube. The test tube was stopped and shaken vigorously for about 30 second. It was then allowed to stand for half an hour. Honeycomb froth indicated the presence of saponins.

\section{TEST FOR FLAVONOIDS:}

$5 \mathrm{ml}$ of dilute ammonia solution were added to a portion of the aqueous filtrate of plant extract followed by addition of concentrated $\mathrm{H} 2 \mathrm{SO} 4$. Formation of yellow color observed in each extract indicated the presence of flavonoids.

\section{TEST FOR STEROIDS:}

One gram of the test substance (plant extracts) was dissolved in a few drops of acetic acid. It was gently warmed and cooled under the tap water and a drop of concentrated sulphuric acid was added along the sides of the test tube. Appearance of green colour indicates the presence of Steroids.

\section{TEST FOR TERPENOIDS (SALKOWSKI TEST):}

$5 \mathrm{ml}$ of each plant part extract was mixed in $2 \mathrm{ml}$ of chloroform, and concentrated $\mathrm{H} 2 \mathrm{SO} 4(3 \mathrm{ml})$ was carefully added to form a layer. Formation of reddish brown coloration at the interface shows the positive results for presence of terpenoids.

\section{TEST FOR REDUCING SUGARS:}

One gram of the aqueous extract was weighed and placed into a test tube. This was diluted using $10 \mathrm{ml}$ of de-ionised distilled water. This was followed by the addition of Fehling's solution. The mixture warmed to $40^{\circ} \mathrm{C}$ in water bath. Development of brick-red precipitate at the bottom of the test tube was indicative of the presence of a reducing sugar. Same procedure was repeated using dimethylsulphoroxide (DMSO) as the diluent for the ethanolic extract.

\section{TEST FOR RESINS:}

Two grams of the ethanolic extract was dissolved in $10 \mathrm{ml}$ of acetic anhydride. A drop of concentrated sulphuric acid was added. Appearance of purple colour, which rapidly changed to violet, was indicative of the presence of resins. Same procedure was repeated using the aqueous extract of the plant material.

\section{TEST ORGANISMS:}

The bacterial species used for the test were Bacillus cereus, Salmonella typhi, Proteus mirablis, Escherichia coli and Pseudomonas aeruginosa. The fungus species used for the test were Aspergillus flavus, Aspergillus niger, Aspergillus fumigates, Candida tropicalis, and Candida albicans. All the stock cultures were obtained from Microlabs, Institute of Research and technology, Vellore Tamilnadu, India. 


\title{
CULTURE MEDIA AND INOCULUM PREPARATION:
}

Nutrient agar broth (Himedia, India) was used as the media for the culturing of bacterial strains. Loops full of all the bacterial cultures were inoculated in the nutrient broth and incubated at $37^{\circ} \mathrm{c}$ for $72 \mathrm{hrs}$ and potato dextrose agar and potato dextrose broth (Himedia, India) were used as the media for the culturing strains. Loops full of all the fungus were inoculated in the Potato dextrose broth (PDA) and incubated at room temperature for $72 \mathrm{hrs}$.

\section{ANTIBACTERIAL ACTIVITY:}

The leaf extracts obtained above were screened for their antibacterial activity in comparison with standard antibiotic ciprofloxacin $(100 \mathrm{mg} / \mathrm{ml})$ in vitro by well diffusion method. Lawn culture was used using the test organism on Muller Hinton Agar (MHA). The inoculated plates were kept aside for few minutes using well cutter, four wells were made in those plates at required distance. In each step of well cutting the well cutter was thoroughly wiped with alcohol. A fixed volume $(0.1 \mathrm{ml})$ of the Calotropis gigantea extract was then introduced into the wells in the increasing concentration. The plates with bacteria were incubated at $37^{\circ} \mathrm{c}$ for 24 hours. The activity of the extract was determined by measuring the diameters of zone of inhibition.

\section{ANTIFUNGAL ACTIVITY:}

The leaf extracts were also screened for their antifungal activity in comparison with standard antibiotic Ketoconazole $(10 \mathrm{mg} / \mathrm{ml})$ in vitro by well diffusion method $(7,8)$. Lawn culture was prepared using the test organism on Sabouraud's Dextrose Agar (SDA). The inoculated plates were kept aside for few minutes using well cutter, four wells were made in those plates at required distance. A fixed volume $(0.1 \mathrm{ml})$ of the Calotropis gigantea extract was then introduced into the wells in the increasing concentration. The plates with fungi were incubated at room temperature for 48 hours. The activity of the extract was determined by measuring the diameters of zone of inhibition.

\section{RESULTS AND DISCUSSION}

\section{PHYTOCHEMICAL ANALYSIS OF BIOACTIVE COMPOUND IN DIFFERENT SOLVENT EXTRACTS OF} CALOTROPIS GIGANTEA

The plant leaf extracts in different solvents were screened for the presence of various bioactive phytochemical compounds. The analysis revealed the presence of cardiac glycosides, saponins, flavonoids, steroids, and terpenoids in most prominent amount while alkaloids and tannins is less amount. Resins absent in organic solvents. These were documented in Table 1.

\begin{tabular}{|l|l|l|l|l|}
\hline Phytochemicals & $\begin{array}{l}\text { Ethanol } \\
\text { Extract }\end{array}$ & $\begin{array}{l}\text { Methanol } \\
\text { Extract }\end{array}$ & $\begin{array}{l}\text { Chloroform } \\
\text { Extracts }\end{array}$ & $\begin{array}{l}\text { n-Hexane } \\
\text { Extracts }\end{array}$ \\
\hline Alkaloids & + & + & + & + \\
\hline Cardiac Glycosides & + & + & + & - \\
\hline Saponins & + & + & + & + \\
\hline Tannins & + & + & - & - \\
\hline Flavnoids & + & + & + & + \\
\hline Steroids & + & + & + & - \\
\hline Terpenoids & + & + & + & + \\
\hline Reducing Sugars & - & + & - & + \\
\hline Resins & - & - & - & - \\
\hline Anthraquinone & - & - & - & - \\
\hline
\end{tabular}

$(+)=$ Positive $\quad(-)=$ Negative

\begin{abstract}
ANTIBACTERIAL EFFICACY ANALYSIS OF DIFFERENT ORGANIC SOLVENT EXTRACTS OF CALOTROPIS GIGANTEA

Antibacterial efficacy of different solvent extracts of Calotropis gigantea is shown in the table2. The Ethanol, and methanol extracts have shown better activity against these pathogenic organisms. Ethanol extract was more effective against Proteus mirablis and Pseudomonas aeruginosa. Methanol extract was more effective against Proteus mirablis and Pseudomonas
\end{abstract}


IOSR Journal of Pharmacy

Vol. 2, Issue 3, May-June, 2012, pp.389-394

aeruginosa. Among these four extracts Ethanol, methanol shows better activity than Chloroform and hexane against the standard drug Ciprofloxacin. The results of antibacterial activity are shown in the table 2 and figure 1.

Table-2 INHIBITION ZONE DIAMETER DIFFERENT EXTRACTS OF CALOTROPIS GIGANTEA AGAINST DIFFERENT BACTERIA (Mean \pm SEM) $(\mathrm{mm})$.

\begin{tabular}{|l|l|l|l|l|l|l|}
\hline Sl. No & Micro organisms & Ciprofloxacin & Ethanol & Methanol & Chloroform & Hexane \\
\hline 1. & Bacillus cereus & $21.30 \pm 0.26$ & Nil & Nil & Nil & Nil \\
\hline 2. & Salmonella typhi & $25.26 \pm 0.25$ & Nil & Nil & Nil & Nil \\
\hline 3. & Proteus mirablis & $20.10 \pm 0.10$ & $12.16 \pm 0.15$ & $6.0 \pm 0.00$ & Nil & Nil \\
\hline 4. & $\begin{array}{l}\text { Escherichia coli } \\
\text { Pseudomonas } \\
\text { aeruginosa }\end{array}$ & $28.33 \pm 0.28$ & Nil & Nil & Nil & Nil \\
\hline 5. & $21.10 \pm 0.17$ & $8.0 \pm 0.00$ & $7.0 \pm 0.00$ & Nil & Nil \\
\hline
\end{tabular}

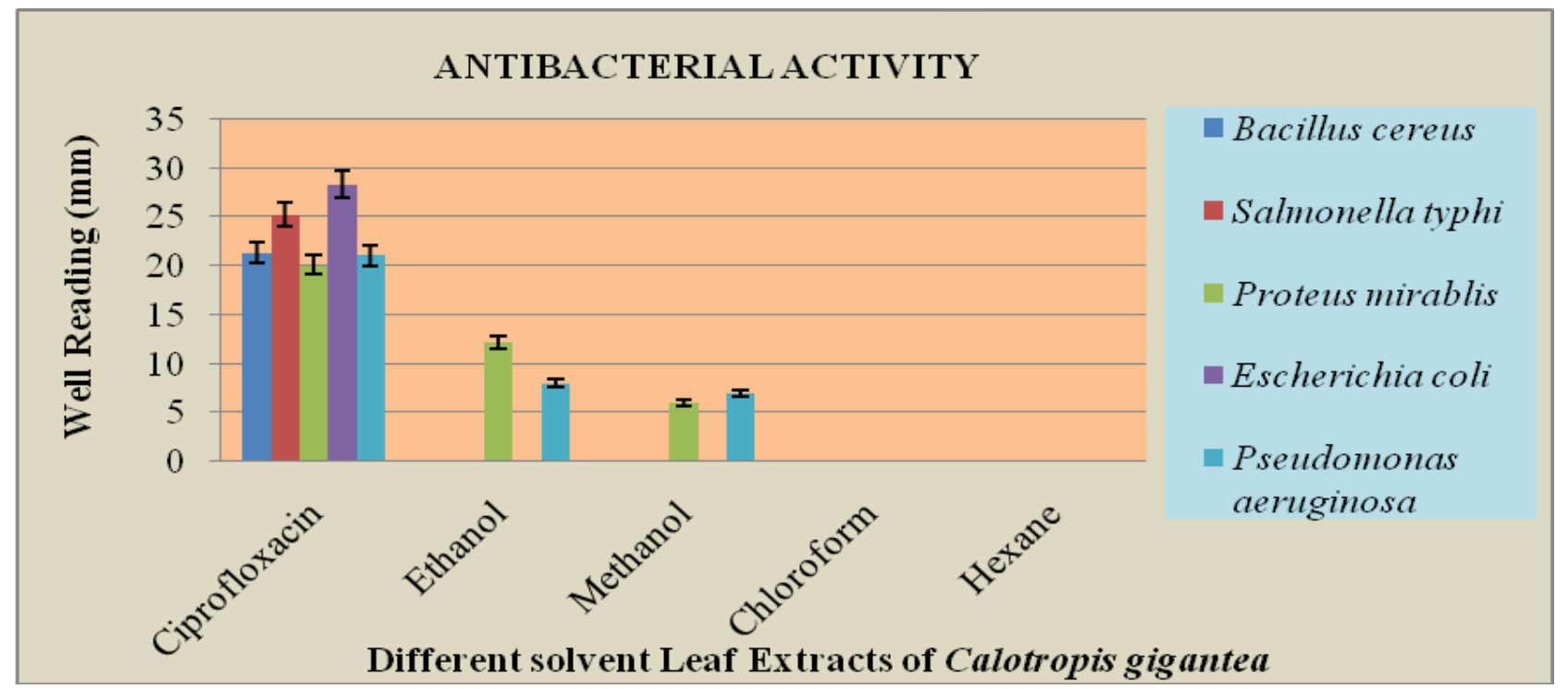

Figure 1: Antibacterial activity of different solvent leaf extracts of Calotropis gigantea against different organisms

\section{ANTIFUNGAL EFFICACY ANALYSIS OF DIFFERENT ORGANIC SOLVENT EXTRACTS OF CALOTROPIS GIGANTEA}

Antifungal efficacy of different solvent extracts of Calotropis gigantea is shown in the table3. The Ethanol, and methanol extracts have shown better activity against these pathogenic organisms. Ethanol extract was more effective against Candida albicans and Candida tropicalis. Methanol extract was more effective against Candida tropicalis and Aspergillus niger. Among these four extracts Ethanol, methanol shows better activity than Chloroform and hexane against the standard drug Ketoconazole. The results of antifungal activity are shown in the table 3 and figure2. 
IOSR Journal of Pharmacy

Vol. 2, Issue 3, May-June, 2012, pp.389-394

Table 3 INHIBITION ZONE DIAMETER DIFFERENT EXTRACTS OF CALOTROPIS GIGANTEA AGAINST

DIFFERENT FUNGUS (Mean \pm SEM) $(\mathrm{mm})$.

\begin{tabular}{|l|l|l|l|l|l|l|}
\hline Sl.No & Micro organisms & Ketoconazole & Ethanol & Methanol & Chloroform & Hexane \\
\hline 1. & Aspergillus flavus & $12.20 \pm 0.20$ & $7.00 \pm 0.0$ & $4.0 \pm 0.00$ & $5.0 \pm 0.0$ & Nil \\
\hline 2. & Aspergillus niger & $10.16 \pm 0.15$ & $5.03 \pm 0.15$ & $7.03 \pm 0.05$ & Nil & Nil \\
\hline 3. & Aspergillus fumigatus & $9.16 \pm 0.15$ & Nil & Nil & Nil & Nil \\
\hline 4. & Candida tropicalis & $15.23 \pm 0.25$ & $13.30 \pm 0.26$ & $10.06 \pm 0.11$ & $5.07 \pm 0.11$ & Nil \\
\hline 5. & Candida albicans & $17.10 \pm 0.17$ & $15.06 \pm 0.11$ & $6.0 \pm 0.00$ & Nil & Nil \\
\hline
\end{tabular}

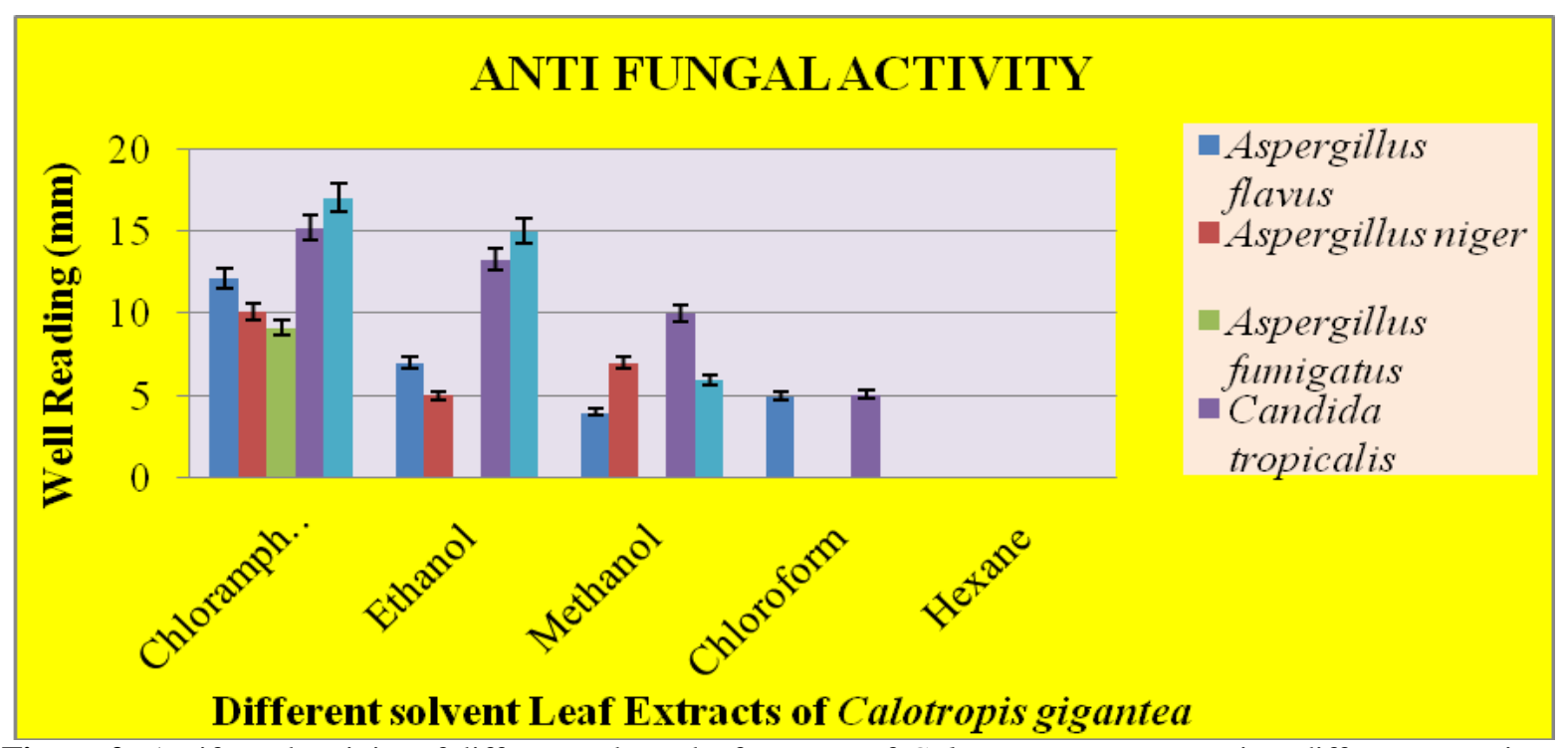

Figure 2: Antifungal activity of different solvent leaf extracts of Calotropis gigantea against different organisms

Antimicrobial activity of different solvent extracts of $C$. gigantea showed varying degrees of antibacterial and antifungal activity against all microorganisms tested $[9,10]$. There are many reports of plants in the family Asclepiadaceae possessing anti-microbial activity [11, 12]. From this study it can be said that, Ethanol and methanol shade dried leaf extract of Calotropis gigantea showed wide range of Antibacterial and Antifungal activity can be used and administered in the ethno medical practice $[13,14]$. The present study has shown a spectrum of antimicrobial activities which provides a support to some tradition uses of these few medicinal plants $[15,16]$. But the effective biomolecules which act as antimicrobial have to be identified isolated and subjected to extensive scientific and pharmacological screening that can be used as sources for new drugs.

\section{CONCLUSION}

The phytochemical analysis revealed the bioactive compounds which are responsible for the Invitro antimicrobial of $C$. gigantea over all fungi and bacteria strains in all extracts could be alkaloids, cardiac glycoside, tannins, saponins, flavonoids, steroids, terpenoids, reducing sugar and resins.

The result of this work suggests that the whole plant extract of C. gigantea has number of medicinal properties. From this work it can be said that the shade dried Calotropis gigantea leaf extract of Ethanol and Methanol has more effective against these pathogenic organisms and can be used for the future references for various other diseases. 
IOSR Journal of Pharmacy

Vol. 2, Issue 3, May-June, 2012, pp.389-394

\section{REFERENCES}

1. Watkins, John, V., Sheehan, thomas, J. and Black, Robert, J. Florida Landscape Plants: Native and Exotic. 2005. University Press of Florida, Gainesville, Florida

2. Sharma A.K.,Kharb R. and kaur R.(2011). Pharmacognostical aspects of Calotropis procera. International Journal of Pharma and Bio Sciences. 2011; 2(3), 480-488.

3. D. Kanimozhi, V. Ratha bai, C. Baskaran et al ationEvalu of Anti Microbial Activity of Acalypha indica. International Journal of Research in Pharmacy and Science. 2012; 2(1), 130-138.

4. Nenaah E.G. and ahmed M.E. Antimicrobial activity of extracts and latex of Calotropis procera and synergistic effect with reference antimicrobials. Research journal of medicinal plants. 2011; 5(6): 706-716.

5. Mamta Goyal and Rashmi Mathur. Antimicrobial Potential and Phytochemical Analysis of Plant Extracts of Calotropis Procera. International journal of drug discovery and herbal research. 2011; 1(3): 138-143.

6. Falguni K. Sheth and Minoo H. Parabia. Ethnobotanical studies and validation of lead: a case study on evaluation of Calotropis sp. on dermal fungal infections. Int. J. of Pharm. \& Life Sci. (IJPLS), Vol. 2, Issue 6: June: 2011, 797800 .

7. Chandrabhan Seniya et al. Antibacterial efficacy and Phytochemical analysis of organic solvent extracts of Calotropis gigantea. J. Chem. Pharm. Res., 2011, 3(6):330-336.

8. Krishnaraj C, Jagan EG, Rajasekar S, et al Synthesis of silver nanoparticles using Acalypha indica leaf extracts and its antibacterial activity against water borne pathogens. Colloids and Surfaces B: Biointerfaces. 2010; 76(1): 5056.

9. Murti Y. Yogi B. and Pathak D. Pharmacognostic standardization of leaves of Calotropis procera (Ait.) R. Br. (Asclepiadaceae). Int J Ayurveda Res. 2010; 1: 14-7.

10. Subramanian S.P. and Saratha V. (2010) Evaluation of Antibacterial Activity of Calotropis gigantea Latex Extract on Selected Pathogenic Bacteria. Journal of Pharmacy Research, 2010; Vol 3, No 3.

11. Sukanya S. L., Sudisha J. , Hariprasad P., Niranjana S. R., Prakash H. S. and Fathima S. K. Antimicrobial activity of leaf extracts of Indian medicinal plants against clinical and phytopathogenic bacteria. African Journal of Biotechnology. 2009; 8 (23): 6677-6682.

12. Okiei, W, Ogunlesi, M.; Ofor, E.; Osibote, E. A. S. Analysis of essential oil constituents in hydro-distillates of Calotropis procera (Ait.) R.Br. Research Journal of Phytochemistry. 2009; 3 (3): 44-53.

13. Juncker T, Schumacher M, Dicato M, Diederich M, UNBS1450 from Calotropis procera as a regulator of signaling pathways involved in proliferation and cell death, Biochem Pharmacol, 2009; 78: 1-10.

14. Yesmin M.N, Uddin S.N., Mubassara S. and Akond M.A. Antioxidant and Antibacterial Activities of Calotropis procera. American-Eurasian J. Agric. \& Environ. Sci., 2008; 4 (5): 550-553.

15. Kuta, F.A, Antifungal effect of Calotropis Procera stem bark on Epidermophyton flocosum and Trichophyton gypseum. African journal of Biotechnology, 2008; 7: 2116-21118.

16. Mei, W.L, Gan, Y.J.; Dai, H.F. Advances in studies on chemical constituents of Antiaris toxicaria and their pharmacological activities. Tradit. Chin. Herb. Drugs 2007, 39, 151-154. 